\title{
Embodied Carbon Emissions in China-US Trade
}

\author{
Zhu $\mathrm{LIU}^{1 *}$, Jing MENG ${ }^{2,3}$, Zhu DENG ${ }^{1}$, Ping LU ${ }^{1}$, Dabo GUAN ${ }^{1}$, Qiang ZHANG ${ }^{1}$, Kebin \\ $\mathrm{He}^{2}$ \& Peng GONG \\ ${ }^{1}$ Ministry of Education Key Laboratory for Earth System Modeling, Department of Earth System Science, \\ Tsinghua University, Beijing 100084, China; \\ ${ }^{2}$ School of Environment, Tsinghua University, Beijing 100084, China;
}

${ }^{3}$ The Bartlett School of Construction and Project Management, University of College London, London WC1E $7 H B, U K$;

* Corresponding author (email: zhuliu@tsinghua.edu.cn)

Acknowledgements: This work was supported by the Natural Science Foundation of China (Grant No. 71874097 \& 41921005), Beijing Natural Science Foundation (Grant No. JQ19032) and Qiu Shi Science and Technologies Foundation

\begin{abstract}
China-US trade holds great significance for the world's political and economic landscape. Since 2018, the US government has imposed additional tariffs on Chinese exports on the grounds of the US trade deficit with China. However, the transfer of pollutants embodied in trade and the differences in environmental costs between China and the US have not been widely recognized. In this study, we quantify the embodied carbon emissions (the "virtual" emissions associated with trade and consumption) in China-US trade by constructing a carbon dioxide emissions inventory and a multiregional input-output model. The study shows that the US benefits from a trade surplus of environmental costs by importing energy-intensive and pollution-intensive products from China, which increases China's environmental pollution and abatement costs. In 2017, $288 \mathrm{MtCO}_{2}$ emissions were associated with products produced in China but finally consumed in the US, and only 46 $\mathrm{MtCO}_{2}$ were associated with the US products that were consumed in China. From this perspective, China-US trade results in a net transfer of $242 \mathrm{MtCO}_{2}$ per year from the US to China, accounting for approximately $5 \%$ of the total $\mathrm{CO}_{2}$ emissions in the US. More importantly, for Chinese products exported to the US, the carbon emissions embodied in one unit of economic value amount to $0.92 \mathrm{~kg} / \$(\mathrm{RMB}: \mathrm{USD}=6.8: 1)$, but for US products exported to China, the carbon emissions embodied in one unit of economic value amount to $0.53 \mathrm{~kg} / \$$, which means China will incur environmental costs that are $74 \%$ higher than those of the US while enjoying the same economic benefits. This environmental trade deficit has burdened China with higher environmental costs than economic benefits. To address this environmental trade deficit, China should actively promote further industrial upgrading and energy structure adjustment and increase investment in innovation and $R \& D$, thereby increasing the value added per unit of export products and reducing the environmental cost of producing export products.
\end{abstract}

Keywords: Carbon Emissions; Embodied Carbon Emissions; Emission Transfer. 


\section{Introduction}

Global trade has profoundly influenced the world. In the context of global trade, the production, assembly, transportation and sales of products span multiple sectors and regions, inevitably leading to significant spatiotemporal differences in economic benefits and environmental and labor costs (Gereffi and Frederick, 2010). In the global industrial chain, the upstream raw material mining and primary manufacturing processes are often labor intensive and resource intensive, resulting in high environmental costs and relatively low economic benefits. Therefore, these upstream manufacturing industries are often outsourced from developed regions through advantages in capital and technology. The recipients of these upstream manufacturing industries, which are often less developed regions, can be "locked in" by the labor-intensive and resource-intensive production mode and become the "pollution haven" of developed regions, resulting in a serious challenge to continuing economic and social development (Zhang et al., 2017).

Since the reform and opening up, China has come to play an important role in global trade due to its labor cost advantages (Guan et al., 2009). In 2017, China's total import and export value was 27.79 trillion RMB, with exports of 15.33 trillion RMB, accounting for $12.77 \%$ of global exports and ranking No. 1 in the world. Exports have become an important economic pillar of China, accounting for $18 \%$ of its current GDP. As China gradually developed into a world manufacturing center, along with a great environmental burden, it gathered the world's major resource-intensive industries, which were outsourced by developed countries. At present, China produces $50 \%$ of the world's primary industrial raw materials, such as cement, steel and coal, resulting in a heavy environmental burden that challenges the country's sustainable development (Guan et al., 2014; Jiang et al., 2015; Meng et al., 2016).

Carbon emissions are one of the most important environmental pressure indicators and have been widely used in the environmental performance evaluations of governments at all levels. Carbon dioxide is one of the most important anthropogenic greenhouse gases, contributing $70 \%$ of the anthropogenic greenhouse effect. Carbon dioxide is mainly produced by burning fossil fuels, such as coal and petroleum, which account for $85 \%$ of the world's total energy consumption. The carbon emissions from the burning of fossil fuels are proportional to the consumption of energy and accompanying raw materials, water and pollutant emissions. Reducing carbon emissions has become a common goal for most countries in their response to climate change. As the world's largest developing country with the highest population and with continuous development in living standards, industrialization and urbanization, China has gradually become the world's top energy consumer and $\mathrm{CO}_{2}$ emitter. China's per capita carbon emissions, however, are only one-third those of the US. The Chinese government has actively been taking responsibility for reducing carbon emissions by making sustainable development in a changing climate a national strategy, setting the goal of reducing carbon emission intensity (carbon emissions per unit of GDP) by $60 \%$ relative to the 2005 level by 2030 (National Development and Reform Commission, 2016), and promising to peak total carbon emissions around 2030 (National Development and Reform Commission, 2015). Due to its significant contribution to $\mathrm{CO}_{2}$ emission reduction and the withdrawal of the US from the Paris Agreement, China appears to be in a position to lead global climate mitigation.

Environmentally extended input-output analysis can be used to quantify the transfer of environmental costs in international trade by combining data on both carbon emissions and trade (Ahmad et al., 2003; Weber and Matthews, 2007; Su and Ang, 2014). Such analysis is able to distinguish the production and the final consumption of carbon emissions (Wiebe et al., 2012a). 
Take China-US trade as an example. Carbon emissions in China due to the production of goods in China that are finally exported to the US are considered the "consumption-based emissions" or "footprint" of the US since the US is where the products are consumed and where the ultimate driver of the emissions comes from. Such embodied emissions have been observed as emissions transferred from developed to developing countries. In relevant studies by Davis et al. (2010), Peters and Hertwich (2008), Peters et al. (2012a), and the author (Meng et al., 2018), a combination of environmentally extended input-output analysis and multiregional input-output analysis (MRIO) has been widely used to quantify the embodied carbon emissions in global trade (Mi et al., 2017; Chen et al., 2018). These studies show the pollution haven effect, i.e., the migration of pollution to undeveloped regions when pollution-intensive industries (such as manufacturing) are outsourced from developed regions due to advantages in technology and resources. China, as a major contributor to global manufacturing, is also the main bearer of embodied pollution and related environmental impacts. Previous studies show that the $\mathrm{CO}_{2}$ emissions contributed by products exported to developed countries have accounted for more than $10 \%$ of China's $\mathrm{CO}_{2}$ emissions since 1997, reaching 25\% in 2007 (1.7 billion tons of $\mathrm{CO}_{2}$ ) (Davis and Caldeira, 2010). In China, Chen et al. (1982), Liu et al. (2011), Li et al. (2016) and other scholars have already developed inputoutput analyses and carried out research on the embodied environmental impacts in international and regional trade. For China-US trade, Yang et al. (2014), Deng et al. (2014) and Zhan et al. (2014) have analyzed the energy or emissions embodied in China-US trade; however, research specifically from the perspective of the environmental cost deficit between China and the US is still lacking. China-US trade is the largest bilateral trade. Since 2018, the China-US trade relationship has become tense, and the US government has unilaterally increased tariffs on US imports of Chinese products to reduce the trade deficit. In this crucial situation, quantitative analysis of the environmental costs between China and the US holds great significance for a comprehensive evaluation of China-US trade relations. However, studies that perform quantitative analysis of the embodied carbon emissions in China-US trade are still limited. Is there a significant environmental cost deficit within China-US trade? What are the causes of the potential unequal carbon emissions in China-US trade? How can the challenge to China's sustainable development posed by China-US trade be dealt with? These important issues have yet to be resolved.

Here, we develop an embodied carbon emissions accounting model and for the first time quantify the embodied carbon emissions in China-US trade based on the Global Trade Analysis Project (GTAP) database and previous researches on multiregional input-output analysis and China's carbon dioxide emissions accounting.

\section{Data and Methodology}

\subsection{Embodied Carbon Emissions Accounting Based on the Input-Output Analysis}

Based on the input-output analysis, hidden environmental costs, including carbon dioxide, can be accounted for through the international industrial chain. The input-output matrix invented by Leontief and the environmentally extended input-output analysis quantitatively describe the economy. These methods are widely used to assess the environmental impact of activities. By extending the single-region input-output matrix to multiple regions, the environmentally 
extended multiregional input-output matrix can track and describe the environmental impacts that take place across regions, such as the shift in environmental impacts caused by bilateral or multilateral trade. This study uses a global trade analysis model from the GTAP to build a multiregional input-output table for 2004, 2007, 2011 and 2014 in 57 sectors around the world, and it quantifies the embodied carbon emissions transfer in trade between 140 countries and regions. For a country, there is:

$$
\boldsymbol{X}^{r}=\boldsymbol{Z}^{r}+\boldsymbol{y}^{r}+\sum_{s} \boldsymbol{e}^{r s}-\sum_{s} \boldsymbol{e}^{s r}
$$

$\boldsymbol{X}^{r}$ is the industry's total output vector for region $r . Z^{r}$ is the local and imported intermediate inputs required in the production process in region $r . \boldsymbol{y}^{r}$ is the local production and import products that meet the final demand, and it can be specifically divided. For household consumption, government consumption and capital formation, $\boldsymbol{e}^{r s}$ is the exports from region $r$ to region $s(r \neq s)$, and $\boldsymbol{e}^{s r}$ is the imports to region $s$ from region $r$. In the model of emissions embodied in bilateral trade (EEBT), by removing imported products that satisfy intermediate production and final demand, the total output of region $r$ meets (Peters and Hertwich, 2008):

$$
\boldsymbol{X}^{r}=\boldsymbol{Z}^{r r}+\boldsymbol{y}^{r r}+\sum_{s} \boldsymbol{e}^{r s}
$$

The imported products in region $r$ satisfy:

$$
\boldsymbol{m}^{r}=\sum_{s} \boldsymbol{e}^{s r}=\sum_{s} \boldsymbol{Z}^{s r}+\sum_{s} \boldsymbol{y}^{s r}
$$

The direct and indirect emissions caused by the final consumption of the production unit are:

$$
\boldsymbol{h}^{r}=\boldsymbol{F}^{r}\left(\boldsymbol{I}-\boldsymbol{A}^{r r}\right)^{-1}
$$

$\boldsymbol{F}^{r}$ is the direct emission intensity vector of region $r$, which is obtained based on the direct carbon dioxide emissions of each sector in the sector's total output (Lin et al., 2014). The $\mathrm{CO}_{2}$ emissions data in this paper are derived from the GTAP database (Aguiar et al., 2016), which includes the carbon emissions from sectors due to fossil energy consumption. According to the research of Liu et al. (2015) on carbon emissions in China, the carbon dioxide emissions of agriculture and industry in the GTAP database are underestimated by $9 \%$. This paper makes the appropriate adjustment in the calculation process. $\boldsymbol{L}=(\boldsymbol{I}-\boldsymbol{A})^{-1}$ is the Lyon Cove inverse matrix, which can reflect the direct or indirect input required per unit of final demand product in the production process. $\left(\boldsymbol{I}-\boldsymbol{A}^{r r}\right)^{-1}$ contains only the local production supply chain and does not include the input of imported products to the intermediate production process.

The direct and indirect emissions from region $\mathrm{r}$ due to the production of products exported to region s are:

$$
\boldsymbol{T}^{r s}=\boldsymbol{F}^{r}\left(\boldsymbol{I}-\boldsymbol{A}^{r r}\right)^{-1} \boldsymbol{e}^{r s}
$$

\subsection{Production-based Emissions Accounting}

According to the $\mathrm{CO}_{2}$ emissions accounting method recommended and widely used by the Intergovernmental Panel on Climate Change (IPCC), the production-side carbon dioxide emissions in a region can be accounted for by activity data $\boldsymbol{A D}$ and corresponding emission factors $\boldsymbol{E} \boldsymbol{F}$, such as carbon dioxide emissions from energy consumption processes (Eggleston et al., 2006; Liu et al., 2015), as shown in Equation 6.

$$
\boldsymbol{E}_{f f}=\boldsymbol{A D} \times \boldsymbol{E F}
$$

Since the carbon emission factor is related to the quality and properties of the energy fuel and the efficiency at the time of combustion, the emission factor can be further decomposed into the net caloric value $\boldsymbol{N C V}$, carbon content $\boldsymbol{C C}$ and oxidation rate $\boldsymbol{O}$ : 


$$
E F=N C V \times C C \times O
$$

Thus, fossil fuel carbon emissions $\boldsymbol{E}_{f f}$ can be estimated by Equation 8.

$$
\boldsymbol{E}_{f f}=\boldsymbol{A D} \times \boldsymbol{C} \boldsymbol{V} \times \boldsymbol{C} \times \boldsymbol{O}
$$

The principle of carbon dioxide emissions accounting for cement production processes is similar to that for carbon emissions from fossil energy consumption, as shown in Equation 9.

$$
\boldsymbol{E}_{\text {industiral }}=\boldsymbol{A D} \times \boldsymbol{E F}
$$

\subsection{Data Source}

In this study, multiregional input-output tables and trade data were obtained from the GTAP database. The latest data in GTAP are for 2014. We assume that the carbon intensity of trade products has remained unchanged in the years since 2014 and extrapolate the analysis to 2017. The China Customs Statistical Yearbook $(2015,2016,2017)$ is used to track changes in various types of import and export products between China and the US in 2015-2017. The emissions data in this study come from the GTAP, whose data originally come from the IEA (International Energy Agency). To better compare and analyze the embodied emissions in China-US trade, GTAP sectors were mapped into 14 main sectors (Table 1). Sectors from different data sources, such as China's trade data from the General Administration of Customs of China, China's GDP and R\&D data from the National Bureau of Statistics of China (NBS), US's GDP data from US Bureau of Economic Analysis (BEA) and US's R\&D data from the OECD, were further mapped onto key manufacturing

\begin{tabular}{|c|c|}
\hline This study & GTAP sectors \\
\hline Agriculture & $\begin{array}{c}\text { Paddy rice/wheat/other grains/veg \& fruit/oil seeds/cane \& beet/plant } \\
\text { fibres/other crops/cattle/other animal products/raw } \\
\text { milk/wool/forestry/fishing }\end{array}$ \\
\hline Mining & Coal/oil/gas/other mining \\
\hline Light industry & $\begin{array}{l}\text { Cattle meat/other meat/vegetable oils/milk/processed } \\
\text { rice/sugar/other food/beverages and tobacco products/textiles/wearing } \\
\text { apparel/leather/lumber/paper \& paper products }\end{array}$ \\
\hline Petroleum, coal products & Petroleum \& coke \\
\hline Chemical, rubber, plastic products & Chemical rubber products \\
\hline Mineral products & Non-metallic minerals \\
\hline Basic metals & Iron $\&$ steel/non-ferrous metals/fabricated metal products \\
\hline Machinery and equipment & Electronic equipment/other machinery \& equipment \\
\hline Transport equipment & Motor vehicles and parts/other transport equipment \\
\hline Other manufacturing & Other manufacturing \\
\hline
\end{tabular}
sectors (Table 2).

Table 1 Mapping of sectors between this study and the GTAP 
Energy production

Construction

Transport
Electricity/gas distribution/water

Construction

Other transport/water transport/air transport/communications

Trade/other financial intermediation/insurance/other business services/recreation \& other services/other services

(government)/dwellings

Table 2 Mapping of sectors from different data sources in the machinery industry

\begin{tabular}{|c|c|c|c|c|}
\hline $\begin{array}{l}\text { This } \\
\text { Study }\end{array}$ & Customs (China) & NBS (China) & BEA (US) & OECD \\
\hline $\begin{array}{l}\text { Chemical } \\
\text { products }\end{array}$ & $\begin{array}{l}\text { Inorganic chemicals; } \\
\text { organic and inorganic } \\
\text { compounds of } \\
\text { precious metals, of } \\
\text { rare earth metals, of } \\
\text { radio-active elements } \\
\text { and of } \\
\text { isotopes/organic } \\
\text { chemicals/pharmaceuti } \\
\text { cal products/tanning or } \\
\text { dyeing extracts; } \\
\text { tannins and their } \\
\text { derivatives; dyes, } \\
\text { pigments and other } \\
\text { colouring matter; } \\
\text { paints, varnishes; } \\
\text { putty, other mastics; } \\
\text { inks/essential oils and } \\
\text { resinoids; perfumery, } \\
\text { cosmetic or toilet } \\
\text { preparations/soap, } \\
\text { organic surface-active } \\
\text { agents; washing, } \\
\text { lubricating, polishing } \\
\text { or scouring } \\
\text { preparations; artificial } \\
\text { or prepared waxes, } \\
\text { candles and similar } \\
\text { articles, modelling } \\
\text { pastes, dental waxes }\end{array}$ & $\begin{array}{l}\text { Manufacture of raw } \\
\text { chemical materials } \\
\text { and chemical } \\
\text { products/manufacture } \\
\text { of chemical } \\
\text { fibers/manufacture of } \\
\text { rubber and plastics } \\
\text { products }\end{array}$ & $\begin{array}{l}\text { Chemical products/plastics } \\
\text { and rubber products }\end{array}$ & $\begin{array}{l}\text { Manufacture of } \\
\text { chemicals and } \\
\text { chemical } \\
\text { products/manufacture } \\
\text { of basic } \\
\text { pharmaceutical } \\
\text { products and } \\
\text { pharmaceutical } \\
\text { preparations/manufact } \\
\text { ure of rubber and } \\
\text { plastic products }\end{array}$ \\
\hline
\end{tabular}




\begin{tabular}{|c|c|c|c|c|}
\hline & $\begin{array}{l}\text { and dental } \\
\text { preparations with a } \\
\text { basis of } \\
\text { plaster/photographic } \\
\text { or cinematographic } \\
\text { goods/chemical } \\
\text { products n.e.c./plastics } \\
\text { and articles } \\
\text { thereof/rubber and } \\
\text { articles thereof }\end{array}$ & & & \\
\hline $\begin{array}{l}\text { Mineral } \\
\text { products }\end{array}$ & $\begin{array}{l}\text { Stone, plaster, cement, } \\
\text { asbestos, mica or } \\
\text { similar materials; } \\
\text { articles } \\
\text { thereof/ceramic } \\
\text { products/glass and } \\
\text { glassware }\end{array}$ & $\begin{array}{l}\text { Manufacture of non- } \\
\text { metallic mineral } \\
\text { products }\end{array}$ & $\begin{array}{l}\text { Nonmetallic mineral } \\
\text { products }\end{array}$ & $\begin{array}{l}\text { Manufacture of other } \\
\text { nonmetallic mineral } \\
\text { products }\end{array}$ \\
\hline Metals & $\begin{array}{l}\text { Iron and steel/iron or } \\
\text { steel articles/copper } \\
\text { and articles } \\
\text { thereof/aluminum and } \\
\text { articles thereof/tools, } \\
\text { implements, cutlery, } \\
\text { spoons and forks, of } \\
\text { base metal; parts } \\
\text { thereof, of base } \\
\text { metal/metal; } \\
\text { miscellaneous } \\
\text { products of base } \\
\text { metal/ores, slag and } \\
\text { ash }\end{array}$ & $\begin{array}{l}\text { Smelting and pressing } \\
\text { of ferrous } \\
\text { metals/smelting and } \\
\text { pressing of non- } \\
\text { ferrous } \\
\text { metals/manufacture of } \\
\text { metal products }\end{array}$ & $\begin{array}{l}\text { Primary metals/fabricated } \\
\text { metal products }\end{array}$ & $\begin{array}{l}\text { Manufacture of basic } \\
\text { metals/manufacture of } \\
\text { fabricated metal } \\
\text { products, except } \\
\text { machinery and } \\
\text { equipment }\end{array}$ \\
\hline $\begin{array}{c}\text { Motor } \\
\text { vehicles }\end{array}$ & $\begin{array}{l}\text { Vehicles; other than } \\
\text { railway or tramway } \\
\text { rolling stock, and parts } \\
\text { and accessories } \\
\text { thereof/aircraft, } \\
\text { spacecraft and parts } \\
\text { thereof }\end{array}$ & $\begin{array}{l}\text { Manufacture of } \\
\text { automobiles/manufact } \\
\text { ure of railway, ship, } \\
\text { aerospace and other } \\
\text { transport equipments }\end{array}$ & $\begin{array}{l}\text { Motor vehicles, bodies and } \\
\text { trailers, and parts/other } \\
\text { transportation equipment }\end{array}$ & $\begin{array}{l}\text { Manufacture of motor } \\
\text { vehicles, trailers and } \\
\text { semi- } \\
\text { trailers/manufacture } \\
\text { of other transport } \\
\text { equipment }\end{array}$ \\
\hline $\begin{array}{l}\text { Clothing } \\
\qquad \& \\
\text { textiles }\end{array}$ & $\begin{array}{l}\text { Apparel and clothing } \\
\text { accessories; knitted or } \\
\text { crocheted/apparel and }\end{array}$ & $\begin{array}{l}\text { Manufacture of } \\
\text { textile/manufacture of } \\
\text { textile, wearing }\end{array}$ & $\begin{array}{l}\text { Textile mills and textile } \\
\text { product mills/apparel and } \\
\text { leather and allied products }\end{array}$ & $\begin{array}{l}\text { Manufacture of } \\
\text { textiles, wearing }\end{array}$ \\
\hline
\end{tabular}




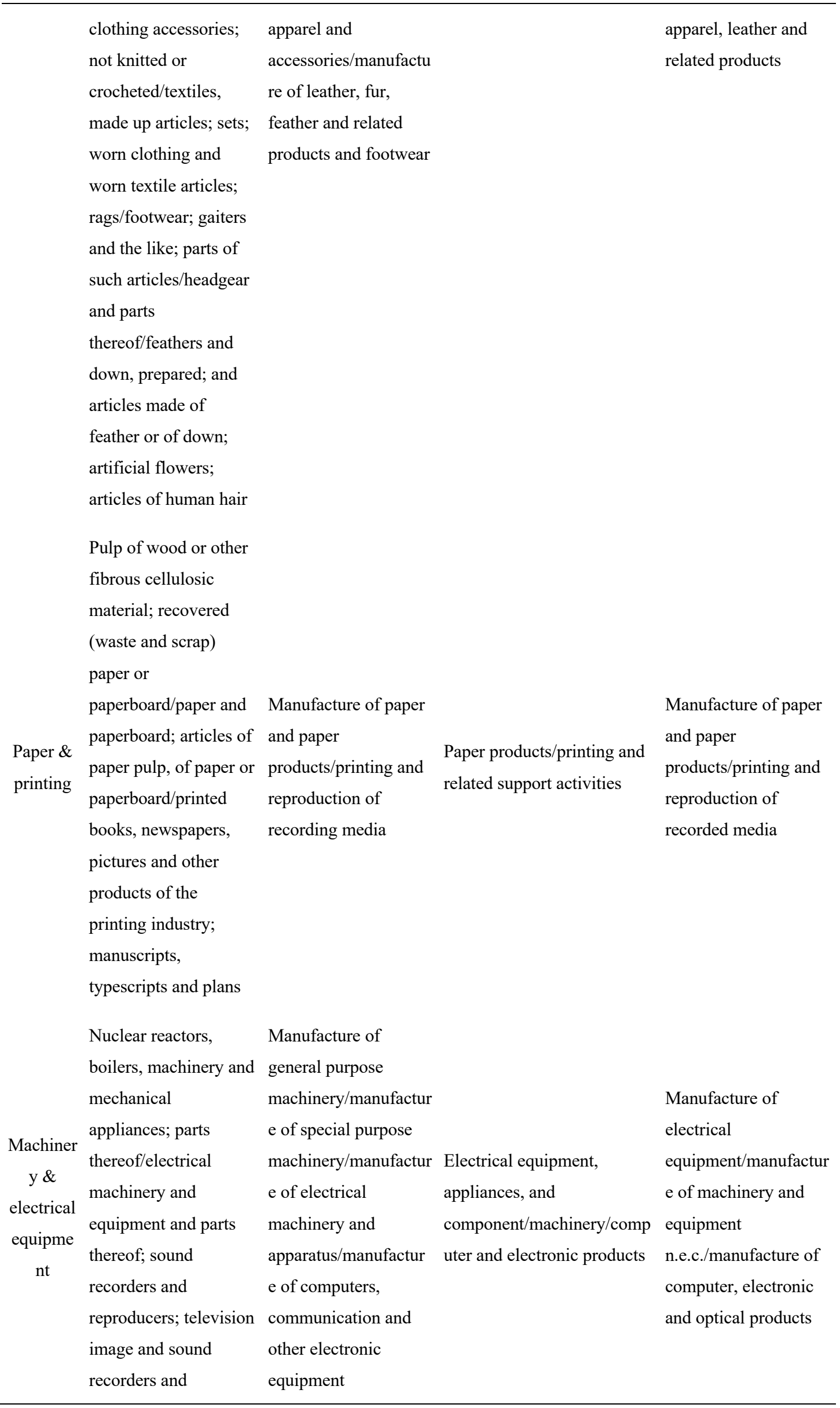




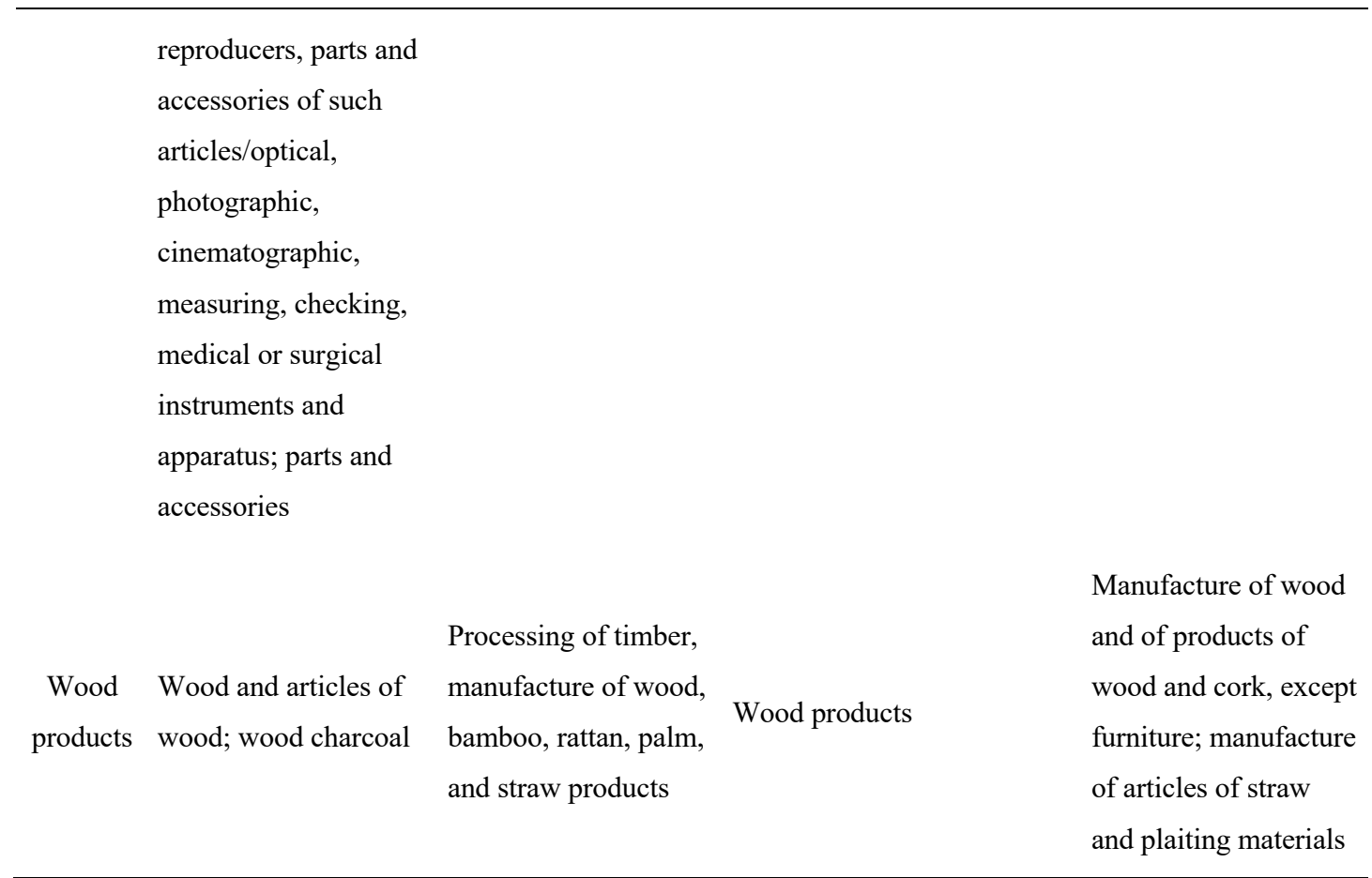

\section{Results}

We build a trade carbon emission accounting model that includes 57 sectors in 140 countries and regions around the world based on the global carbon emissions database and multiregional inputoutput table. Then we apply the model to quantify embodied carbon emissions in global trade in 2004, 2007, 2011 and 2014 and extrapolate the analysis to 2017. The results show that the total amount of embodied carbon emissions in global trade was approximately $9 \mathrm{GtCO}_{2}$ in 2017, accounting for one-fourth of the world's total emissions. The embodied carbon emissions in global trade experienced rapid growth from 2000 to 2011, some fluctuations and a significant slowdown after 2011 due to the global economic crisis. The embodied carbon emissions in Chinese exports amount to $1.59 \mathrm{GtCO}_{2}$, which is approximately one-sixth of China's total carbon emissions.

China-US trade is the world's largest bilateral country trade. The carbon emissions embodied in China-US trade are also the highest among all international trades. The results show that the carbon dioxide emissions embodied in China-US trade amounted to $334 \mathrm{MtCO}_{2}$ in 2017, of which 288 $\mathrm{MtCO}_{2}$ were associated with Chinese exports consumed by the US, while $46 \mathrm{MtCO}_{2}$ were associated with US exports consumed by China. Therefore, $242 \mathrm{MtCO}_{2}$ are transferred from the US to China due to the US trade surplus. 


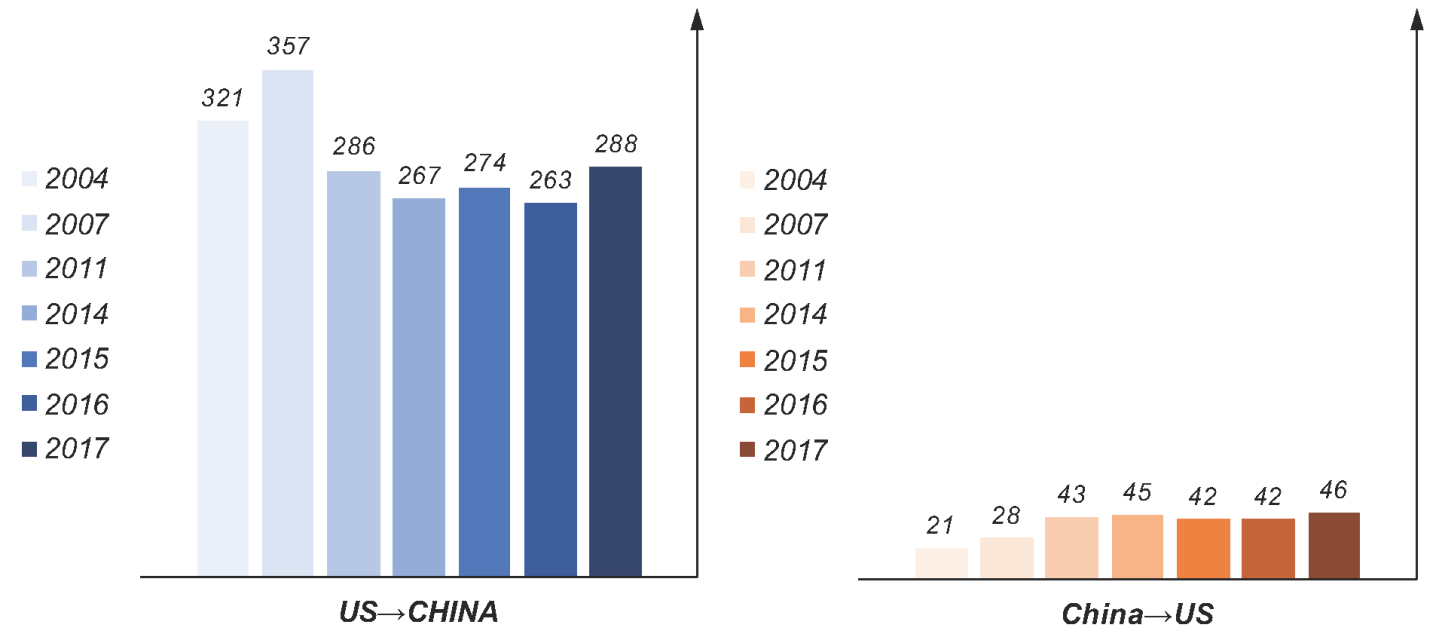

Figure 1 Embodied carbon emissions in China-US trade (unit: $\mathrm{MtCO}_{2}$ )

The structures of carbon emissions embodied in China's export and US's export show significantly differences. China's exports to the US are mainly from the manufacturing industry, while US exports to China are more diverse, showing a wide range from manufacturing to transportation equipment and agricultural products. Figure 2 shows the sectoral contribution to the embodied carbon emissions in China-US trade in 2017. Among the total emissions embodied in China's exports to the US, "machinery and equipment" is the largest contributor, accounting for $43.6 \%$, followed by "light industry" (16.2\%) and "chemical products" (12.0\%). In contrast, "chemical products", "machinery and equipment", "transportation equipment" and "agriculture" are the largest contributors to the emissions embodied in the US's exports to China, accounting for $17.3 \%, 16.6 \%$, $14.8 \%$ and $11.7 \%$ respectively.
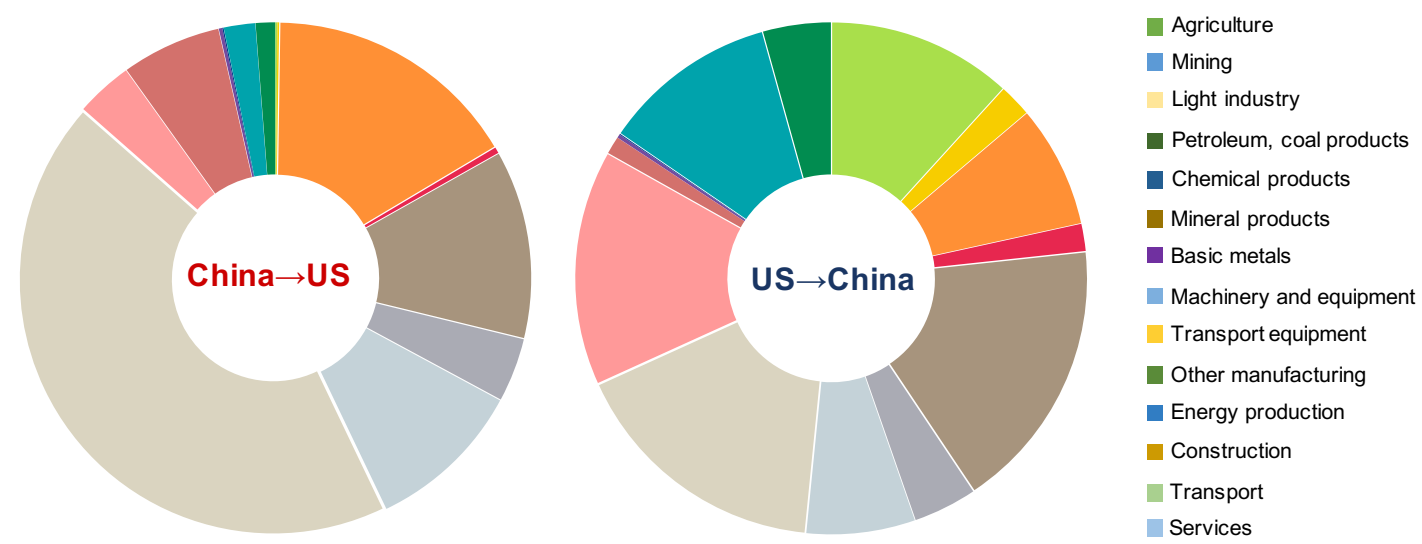

Figure 2 Sectoral contribution to the carbon emissions embodied in China-US trade in 2017

In terms of the absolute amount of carbon emissions embodied in China-US trade (Figure 3), agriculture and mining are the only two sectors for which the embodied emissions are higher for US exports to China, with the remaining sectors showing higher values for Chinese exports consumed by the US. These results show that the US avoids direct carbon emissions by importing carbonintensive machinery and equipment products and chemical products from China, resulting in carbon 
emissions transferred to China by trade. At the same time, China receives the carbon emissions transferred from the US as well as economic benefits.

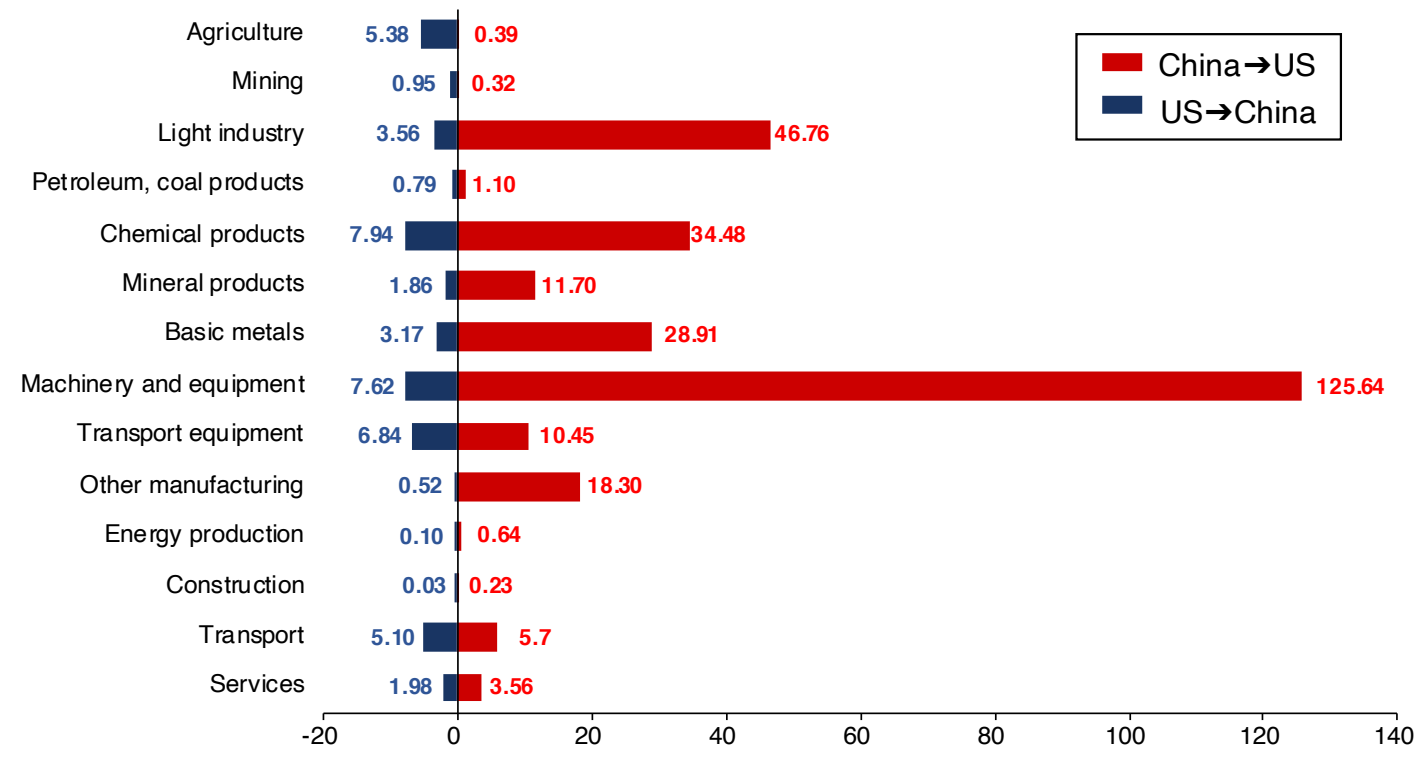

Figure 3 Carbon emissions embodied in China-US trade by sectors in 2017 (unit: $\mathrm{MtCO}_{2}$ )

This study uses carbon intensity to comprehensively evaluate the economic benefits and environmental costs in China-US trade. Carbon intensity is the carbon emissions per unit of economic value, which is characterized by the environmental cost (carbon dioxide emissions) generated by one unit of economic income (one US dollar). The carbon intensity is 0.92 $\mathrm{kg} / \$$ (RMB: USD $=6.8: 1$ ) for Chinese products imported by the US, and $0.53 \mathrm{~kg} / \mathrm{\$}$ for US products imported by China. Chinese products show a carbon intensity that is $74 \%$ higher than that of US products, implying that China's environmental costs per US dollar are nearly twice that of the US in China-US trade. The carbon intensities of embodied emissions by sectors (Figure 4) indicate that China's carbon emission intensity in most sectors is higher than that of the US.

Due to China's relatively low labor costs and other reasons, the carbon intensity of China's export products is generally high. For example, we quantify the carbon dioxide emissions per unit of product output during the life cycle of major industrial products and find that in glass manufacturing, China is in line with the EU average. In the production process of industrial materials such as glass, steel, iron, and aluminum, the carbon dioxide emissions per unit of product output are several times those of the EU. However, the unit price of most Chinese industrial products is lower than that of European and American countries. In other words, China will pay several times the resources and environmental costs of other countries on the premise of the same economic benefits. 


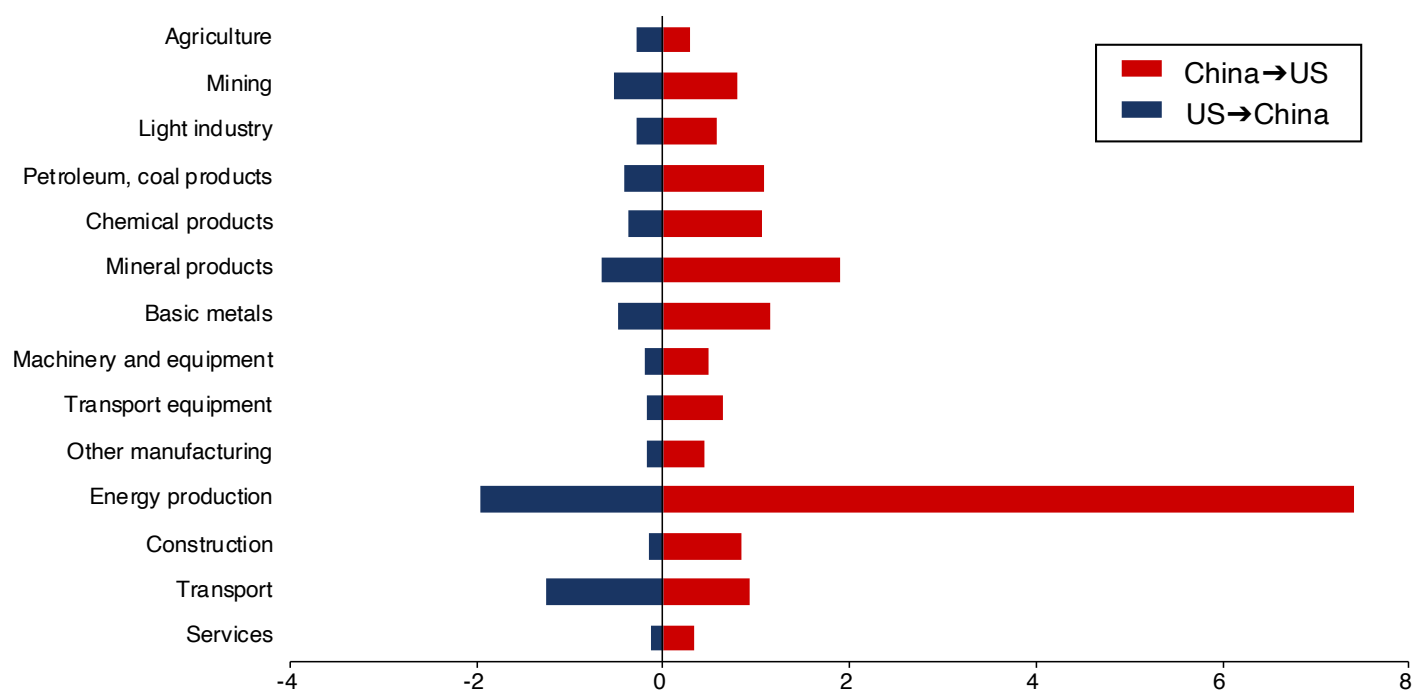

Figure 4 Carbon intensity embodied in China-US trade in 2017 by sectors (unit: one kilogram per US dollar)

However, the environmental cost deficit of embodied carbon emissions in China-US trade does not simply depend on the economic cost of Chinese and US's products. Analyzing and comparing the R\&D investment of key sectors and the economic output of unit emissions (Figure 5), we find that higher R\&D investment in products leads to higher economic output, which thus effectively reduces the environmental cost. For example, in the US, the economic benefits per unit of carbon emissions of aerospace equipment is triple those of machinery and electrical equipment, however, the R\&D investment per unit of carbon emissions of aerospace equipment is seven times to machinery and electrical equipment. In 2017, China's machinery and electrical equipment exported to the US accounted for $56 \%$ of Chinese total exports, while the US's most exported products to China are aerospace products, accounting for $13 \%$ of total exports. The economic value per unit carbon emissions of aerospace products exported from the US to China is as high as $\$ 33,000 /$ ton of carbon dioxide. The economic value of machinery and electrical equipment exported from China to the US is only $\$ 8,000 /$ ton of carbon dioxide. The result shows that the economic output per unit carbon emissions of aerospace products from the US is more than four times that of machinery and electrical equipment from China, indicating lower R\&D investment and value added in Chinese exports and higher value added in the US's exports. In terms of the comparison of the same sector, for example, the R\&D investment per unit of carbon emissions of US aerospace equipment is as high as $\$ 8,000 /$ ton of carbon dioxide, and for the corresponding Chinese aerospace equipment per unit carbon, the $\mathrm{R} \& \mathrm{D}$ investment per unit of carbon emissions is only $\$ 1,000 /$ ton of $\mathrm{CO}_{2}$. Low labor cost in China is a key factor to the successful sale of China's general manufacturing products in the international market. However, relatively insufficient $R \& D$ investment is also an important factor leading to lower economic output per unit environmental cost in China. One of the future development directions for China's manufacturing industry is to gradually upgrade from lower 
$R \& D$ investment and value-added manufacturing to high-tech and high value-added industries.

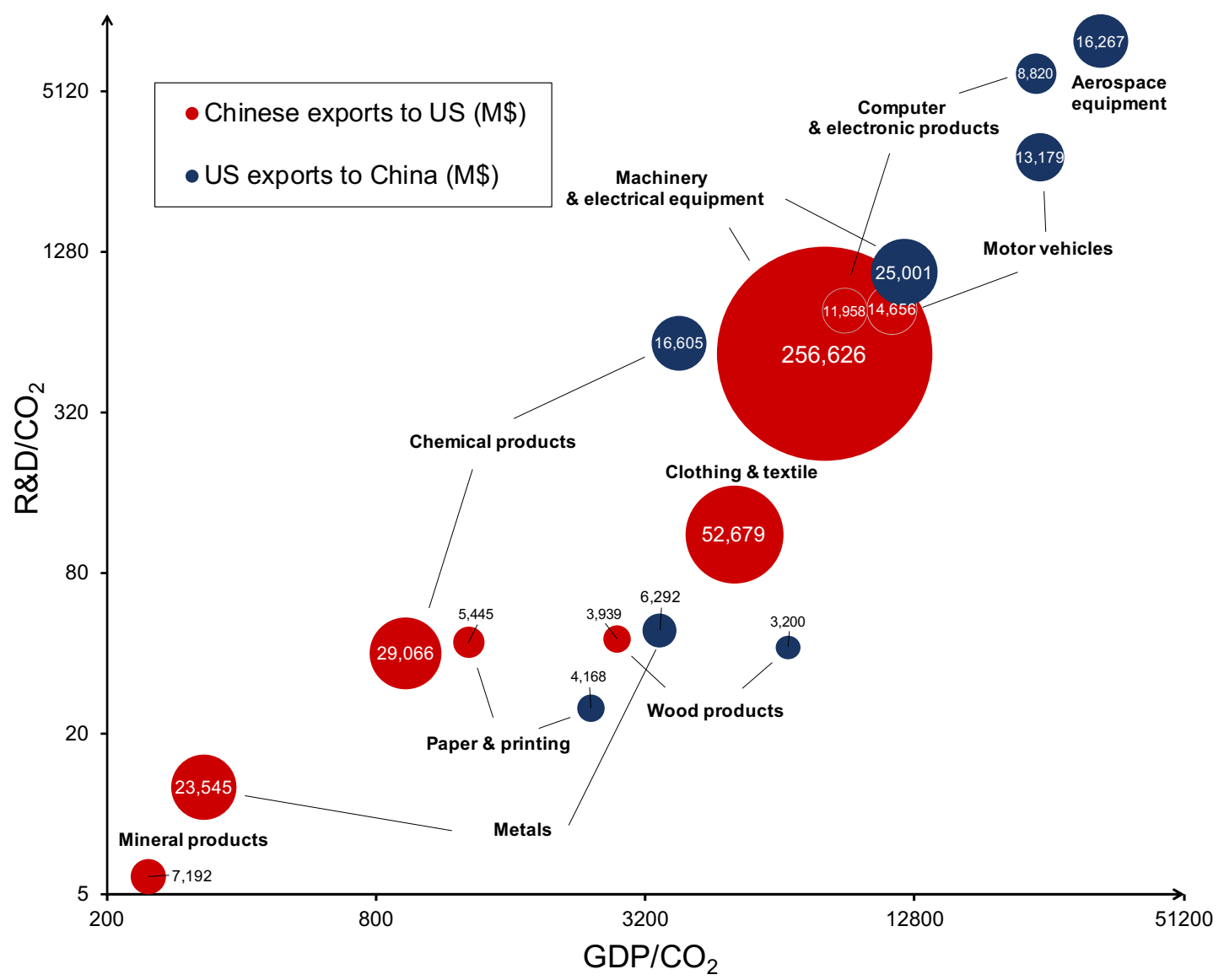

Figure 5 Comparison of economic output per carbon emissions $\left(\mathrm{GDP} / \mathrm{CO}_{2}\right)$ and $\mathrm{R} \& \mathrm{D}$ investment per unit carbon emissions ( $\mathrm{R} \& \mathrm{D} / \mathrm{CO}_{2}$ ) embodied in China-US trade by key sectors in 2017 (unit: one dollar per ton)

\section{Conclusion and Discussion}

This study obtains the following key findings:

1) From the perspective of carbon emissions embodied in trade, China has a significant environmental cost deficit with the US. The US imports $242 \mathrm{MtCO}_{2}$ emissions from China through its net imports of Chinese products. In 2017, $288 \mathrm{MtCO}_{2}$ were imported from China to the US, while $46 \mathrm{MtCO}_{2}$ were imported from the US to China.

2) In China-US trade, the environmental costs incurred by China are not consistent with the economic benefits obtained. The embodied carbon intensity of Chinese exports to the US is $74 \%$ higher than the embodied carbon emission intensity of US exports to China, indicating that China pays energy and environmental costs that are approximately $74 \%$ higher than those paid by the US. 3) The economic output per unit carbon emissions in the same sectors in the US is generally higher than that in China. In terms of the structure of exports by sectors, China's export is mostly concentrated in machinery and manufacturing equipment, while US's exports are concentrated in high-end manufacturing and service industries such as high value-added aerospace equipment. The economic benefit of unit carbon emissions in aerospace equipment products from the US is more than four times the economic benefit of unit carbon emissions in machinery and electrical equipment from China. 
4) The embodied carbon analysis in the manufacturing industry shows that higher economic output is achieved on the basis of higher R\&D investment. For example, on the basis of more than seven times the R\&D investment per unit carbon emissions, the economic benefits per unit carbon emissions for aerospace equipment in the US are approximately three times those of machinery and electrical equipment. Therefore, China needs to further expand its R\&D investment and increase the competitiveness of its high-end manufacturing industry in the international market.

This study shows that in China-US trade, China's economic and trade surplus is accompanied by an environmental trade deficit and that China pays higher environmental costs under the same economic benefits. As a consumer of products, the US has certain moral and economic responsibilities for China's environmental cost deficit with US. However, since 2018, the US has taken the lead in imposing tariffs on the grounds of its trade deficit with China. Its practice ignores and evades the transfer of the US environmental cost to China in China-US trade.

From the perspective of reducing its own environmental costs, on the one hand, China needs to further increase investment in innovation, transform its mode of economic growth, promote further industrial upgrading and adjustment, increase the content of its product technology, its value added and its international competitiveness, and ultimately achieve innovation-driven sustainable development. At present, the R\&D investment of China's manufacturing unit products is still far lower than that of developed countries. Further increasing $R \& D$ investment and increasing the value added of manufacturing products will enable China to narrow the gap in the economic benefits of unit costs in international trade between itself and developed countries. On the other hand, China should take advantage of strategic opportunities such as the "Belt and Road Initiative" to promote the construction of an ecological civilization and to actively build a global industrial ecosystem. The vast number of developing countries and countries along the "Belt and Road" have broad market prospects and unique resource advantages. By promoting infrastructure construction and other activities to form a broader industrial ecosystem, the optimal allocation of resource endowments and manpower inputs can be achieved. At the same time, dispersing the manufacturing sector in different countries and regions will help to avoid the concentration of pollutants and reduce the environmental impacts and health losses in densely populated areas. Building a cross-regional and cross-industry resource utilization and recycling system will also provide a viable way to eliminate pollutants in the context of global trade and to solve global environmental problems. China needs to continuously improve the competitiveness of its innovation-driven industry under the combined effects of policies, technologies and markets.

The uncertainty mainly comes from (1) the multiregional input-output table. The differences between databases, including the GTAP, WIOD, and EORA, are no more than 13\% (Peters et al., 2012b). The research of Owen et al. (2014) indicates that the uncertainties in carbon footprint accounting come from emissions data instead of economic data. In this study, the emissions data comes from IEA, which is also the data source of emissions data in databases such as WIOD and EORA. The GTAP has the most sectors compared to other databases and is widely used in global trade research (Davis and Caldeira, 2010; Wiebe et al., 2012b; Andrew and Peters, 2013). (2) The latest global multiregional input-output table was released in 2014. The assumption that carbon emission intensity is constant is used in calculating the embodied emissions in 2017, which will cause certain errors. (3) Because the classification of sectors in the GTAP database is not consistent with the classification of the General Administration of Customs of China, the sectors were split or 
merged for comparison. In general, the uncertainty mainly comes from the limitations and hysteresis of the data, which can be improved in the future if such limitations are overcome. 


\section{References:}

Aguiar A, Narayanan B, McDougall R. 2016. An overview of the GTAP 9 data base. Journal of Global Economic Analysis, 1:181-208

Ahmad N, Wyckoff A. 2003. Carbon dioxide emissions embodied in international trade of goods. OECD Science, Technology and Industry Working Papers. Paris: OECD Publishing. No. 2003/15

Andrew RM, Peters GP. 2013. A multi-region input-output table based on the Global Trade Analysis Project Database (GTAP-MRIO). Economic Systems Research, 25:99-121

Chen X K. 1982. Economic Mathematical Methods and Models (in Chinese). Beijing: China Financial and Economic Publishing House.

Chen Z-M, Ohshita S, Lenzen M, Wiedmann T, Jiborn M, Chen B, Lester L, Guan D, Meng J, Xu S. 2018.

Consumption-based greenhouse gas emissions accounting with capital stock change highlights dynamics of fast-developing countries. Nature communications, 9:3581

Davis SJ, Caldeira K. 2010. Consumption-based accounting of $\mathrm{CO}_{2}$ emissions. Proceedings of the National Academy of Sciences, 107:5687-5692

Deng R R, Chen M. 2014. Concealed Carbon Emission in Sino-US Trade: Analysis Based on I-O SDA Model (in Chinese). Business Review, 26:46-57

Eggleston S, Buendia L, Miwa K, Ngara T, Tanabe K. 2006. 2006 IPCC guidelines for national greenhouse gas inventories: Institute for Global Environmental Strategies Hayama, Japan.

Gereffi G, Frederick S. 2010. The global apparel value chain, trade and the crisis: challenges and opportunities for developing countries: The World Bank.

Guan D, Peters GP, Weber CL, Hubacek K. 2009. Journey to world top emitter: An analysis of the driving forces of China's recent $\mathrm{CO}_{2}$ emissions surge. Geophysical Research Letters, 36:L04709

Guan D, Su X, Zhang Q, Peters GP, Liu Z, Lei Y, He K. 2014. The socioeconomic drivers of China's primary $\mathrm{PM}_{2.5}$ emissions. Environmental Research Letters, 9:024010

Jiang X, Zhang Q, Zhao H, Geng G, Peng L, Guan D, Kan H, Huo H, Lin J, Brauer M. 2015. Revealing the hidden health costs embodied in Chinese exports. Environmental science \& technology, 49:4381-4388

Li S T, Qi S C, He J W. 2016. 2007China's extended input-output table: compilation and application (in Chinese). Beijing: Economic Science Press.

Lin J, Pan D, Davis SJ, Zhang Q, He K, Wang C, Streets DG, Wuebbles DJ, Guan D. 2014. China's international trade and air pollution in the United States. Proceedings of the National Academy of Sciences, 111:17361741

Liu H G, Liu W D, Liu Z G. 2011. The quantitative study on inter-regional industry transfer (in Chinese). China Industrial Economics, 6:79-88

Liu Z, Guan D, Wei W, Davis SJ, Ciais P, Bai J, Peng S, Zhang Q, Hubacek K, Marland G. 2015. Reduced carbon emission estimates from fossil fuel combustion and cement production in China. Nature, 524:335-338

Meng J, Liu J, Xu Y, Guan D, Liu Z, Huang Y, Tao S. 2016. Globalization and pollution: tele-connecting local primary PM2. 5 emissions to global consumption. Proceedings of the Royal Society A: Mathematical, Physical and Engineering Sciences, 472(2195):20160380.

Meng J, Mi Z, Guan D, Li J, Tao S, Li Y, Feng K, Liu J, Liu Z, Wang X, Zhang Q, Davis SJ. 2018. The rise of South-South trade and its effect on global $\mathrm{CO}_{2}$ emissions. Nature Communications, 9:1871

Mi Z, Meng J, Guan D, Shan Y, Song M, Wei Y, Liu Z, Hubacek K. 2017. Chinese $\mathrm{CO}_{2}$ emission flows have reversed since the global financial crisis. Nature Communications, 8:1712

National Bureau of Statistics. 2019. Statistical communiqué of the People's Republic of China on the 2018 national economic and social development. 
National Development and Reform Commision. 2015. Enhanced actions on climate change:

China's intended nationally determined contributions.

Owen A, Steen-Olsen K, Barrett J, Wiedmann T, Lenzen M. 2014. A structural decomposition approach to comparing MRIO databases. Economic Systems Research, 26:262-283

Peters GP, Hertwich EG. 2008. $\mathrm{CO}_{2}$ embodied in international trade with implications for global climate policy. Environmental Science \& Technology, 42:1401-1407

Peters GP, Marland G, Le Quéré C, Boden T, Canadell JG, Raupach MR. 2012a. Rapid growth in $\mathrm{CO}_{2}$ emissions after the 2008-2009 global financial crisis. Nature Climate Change, 2:2-4

Peters GP, Davis SJ, Andrew R. 2012b. A synthesis of carbon in international trade. Biogeosciences, 9:3247-3276

$\mathrm{Su}$ B, Ang B. 2014. Input-output analysis of $\mathrm{CO}_{2}$ emissions embodied in trade: a multi-region model for China. Applied Energy, 114:377-384

Weber CL, Matthews HS. 2007. Embodied environmental emissions in US international trade, 1997-2004. In: ACS Publications.

Wiebe KS, Bruckner M, Giljum S, Lutz C. 2012a. Calculating energy-related $\mathrm{CO}_{2}$ emissions embodied in international trade using a global input-output model. Economic Systems Research, 24:113-139

Wiebe KS, Bruckner M, Giljum S, Lutz C, Polzin C. 2012b. Carbon and materials embodied in the international trade of emerging economies a multiregional input-output assessment of trends between 1995 and 2005. Journal of Industrial Ecology, 16:636-646

Yang R, Long R, Yue T, Shi H. 2014. Calculation of embodied energy in Sino-USA trade: 1997-2011. Energy Policy, 72:110-119

Zhan J, Ye J. 2014. Study on the measurement and influencing factors of embodied carbon emissions in the SinoUS trade (in Chinese). Journal of Guangdong University of Business Studies, 29:36-42

Zhang Z, Zhu K, Hewings GJ. 2017. A multi-regional input-output analysis of the pollution haven hypothesis from the perspective of global production fragmentation. Energy Economics, 64:13-23 